\title{
Yield and quality of two hulless barley varieties after inoculation with Fusarium culmorum
}

\author{
Ivana Polišenská*1, Kateřina Vaculová ${ }^{1}$, Ondřej Jirsa ${ }^{1}$, Irena Sedláčková ${ }^{1}$, Jan Frydrych $^{2}$ \\ ${ }^{1}$ Agrotest Fyto, Ltd., Havlíčkova 2787, 76701 Kroměřǐz, Czech Republic \\ ${ }^{2}$ OSEVA Development and Research, Ltd., Hamerská 698, 75654 Zubří, Czech Republic \\ *Corresponding author:polisenska@vukrom.cz
}

\begin{abstract}
The effect of $F$. culmorum inoculation on the yield and quality of grain of AF Cesar and AF Lucius barley varieties was monitored. Field experiments were conducted between 2015-2017 at two locations. In grain harvested from plots grown under natural infection conditions, the deoxynivalenol content was very low. Inoculation caused a decline in germination, a certain reduction in yield and a change in some qualitative parameters (reduction in protein and fiber content, increase in starch content), but the effect of inoculation was weak and significantly influenced by the environment and the variety. The $\beta$-glucan content was not affected by inoculation. The varieties differed significantly from each other in $\beta$-glucan content (AF Cesar > AF Lucius). The deoxynivalenol content of both varieties was comparable after the inoculation while it differed under conditions of the natural infection (AF Cesar $<$ AF Lucius).
\end{abstract}

Key words: hulless barley, Fusarium culmorum, $\beta$-glucans, deoxynivalenol, yield, quality

\section{Introduction}

For thousands of years, barley was the dominant crop for feeding, production of fermented drinks and also, especially in its hulless form (Hordeum vulgare L. var. nudum Hook. f.), used as food. Hulless, called also naked barley, is a form of domesticated barley with an easier-to-remove hull which has been used for centuries for preparing porridge, and both fermented and unfermented bread. Current epidemiological studies have consistently shown that regular consumption of whole grain barley reduces the risk of developing chronic diseases. The presence of barley fiber, especially $\beta$-glucans, has been largely credited for these health benefits (Idehen et al., 2017). In general, using the whole grain cereals as a foodstuff, special attention should be paid to their contamination with Fusarium mycotoxins as their concentration is usually higher in outer grain layers and lower in the inner tissues (Tibola et al., 2015).

Most studies aimed at Fusarium head blight (FHB) and its harmfulness are focused on wheat, but Fusarium spp. pathogens infect commonly also barley and other cereal species. There are three main negative consequences of FHB cereal infection: loss of grain yield, impaired technological quality, and contamination of grain by Fusarium mycotoxins. The European Union has established maximum limits (ML) for some Fusarium mycotoxins in foodstuffs, including cereals and cereal products (Commission Regulation (EC) No. 1881/2006) (EU, 2006). ML for Fusarium mycotoxins in unprocessed barley are given for deoxynivalenol (DON, $1250 \mu \mathrm{g} / \mathrm{kg}$ ) and for zearalenone (ZEA, $100 \mu \mathrm{g} / \mathrm{kg}$ ). Yield depression as a negative consequence of FHB infection can be caused by lower number of kernels in cereal head and/or lower weight of infected kernel. Biochemical changes in grain composition as a consequence of FHB can have two main reasons. The first one is the presence of enzymes produced by the invading fungus/fungi, the second one is impaired synthesis of grain components. Fusarium spp. can produce enzymes capable of modifying and decomposing storage matter of grain, such as proteins and carbohydrates, in order to be more accessible for their utilization. This was documented mainly for wheat (Eggert et al., 2010a; Kreuzberger et al., 2015), but also for barley (Pekkarinen et al., 2000), including its hulless form (Eggert et al. 2010b; Eggert and Pawelzik, 2011). The influence of Fusarium infection on barley quality has been studied mainly from the point of view of the malting and brewing process. A significant influence of FHB on yield and several functional parameters of barley grain related to malting and brewing quality was reported by Sarlin et al. (2005), Schwarz (2003) and Schwarz et al. (2006). The knowledge about the influence of FHB on naked barley as a foodstuff from the point of view of nutritional composition and quality is very limited. Eggert and Pawelzik (2011) reported that the protein content of naked barley was not significantly changed after even severe Fusarium infection, but they found differences in protein content between locations. We studied the yield, quality (germination, TKW, TW, content of crude protein, $\beta$-glucans, starch, fat and fiber) and DON content of two varieties of hulless barley (AF Cesar, AF Lucius) after inoculation with Fusarium culmorum. These parameters in grain harvested from inoculated plots in the 3-year field trial at 2 locations were compared with those in grain from non-inoculated plots.

\section{Material and methods}

\subsection{Plant material and field trials}

Field experiments were conducted at two locations (Kroměříz - KM, Zubří - ZB) during the three growing seasons 2015-2017. Kroměříz (altitude 235 m, warm and moderately wet region, average annual temperature $9.2^{\circ} \mathrm{C}$, 
Table 1: Description of weather conditions at the trial locations (Kroměř ǐ - KM, Zubř́ - ZB), data of sowing, inoculation (first spray, second spray after 3 days), and harvest.

\begin{tabular}{|l|c|c|r|r|r|r|r|}
\hline Location & Year & Mean temperature* & Rainfalls* & \multicolumn{1}{|c|}{ Sowing } & \multicolumn{2}{|l|}{ Inoculation } & Harvest \\
\hline & & ${ }^{\circ} \mathrm{C}$ & $\mathrm{mm}$ & & \multicolumn{1}{c|}{ AF Cesar } & \multicolumn{1}{c|}{ AF Lucius } & \\
\hline KM & 2015 & 16.0 & 167 & 24-Mar & 8-Jun & 12-Jun & 30-Jul \\
\hline & 2016 & 15.2 & 325 & 30-Mar & 11-Jun & 14-Jun & 27-Jul \\
\hline & 2017 & 16.1 & 242 & 28-Mar & 8-Jun & 12-Jun & 22-Jul \\
\hline ZB & 2015 & 15.2 & 204 & 14-Apr & 18-Jun & 18-Jun & 3-Aug \\
\hline & 2016 & 15.0 & 487 & 5-Apr & 24-Jun & 24-Jun & 9-Aug \\
\hline & 2017 & 15.1 & 353 & 30-Mar & 19-Jun & 19-Jun & 24-Jul \\
\hline
\end{tabular}

* mean daily temperature and sum of precipitation from 21 March to 10 August

avarage total annual precipitation $576 \mathrm{~mm}$ ). Zubří (altitude $345 \mathrm{~m}$, slightly warm region, average annual temperature $7.5^{\circ} \mathrm{C}$, average total annual precipitation $865 \mathrm{~mm}$ ). Two hulless spring barley cultivars were sown, AF Cesar and AF Lucius, year of registration 2014 and 2009, respectively, both Agro-test Fyto, Ltd. The cereals were sown in one block with a plot size of $10 \mathrm{~m}^{2}$ and 4 randomized replicates. Inoculation with $F$. culmorum was done at the flowering stage according to the method of Tvarǔžek et al. (2012) by spraying ears (twice, in a 3-day interval) with a spore suspension (concentration 1 million conidia in $1 \mathrm{ml}$ water). The trials were not treated by fungicides. Application of $\mathrm{N}$ fertilization: before sowing (NPK, $40 \mathrm{~kg} \mathrm{~N} / \mathrm{ha}$ ), in tillering (CAN, $40 \mathrm{~kg} \mathrm{~N} / \mathrm{ha}$ ). Weather conditions in particular harvest years and some agronomical data are summarised in Table 1.

\subsection{Grain quality evaluation}

Barley grain quality was characterised by TW, TKW, germination, crude protein content (CPC), and content of starch, fiber, $\beta$-glucan and fat. TW was determined according to the ISO 7971-3:2009. CPC $(\mathrm{N} \times 6.25)$ was determined by the Dumas method according to the ICC Standard No. 167 using a LECO FP-528 analyser (LECO Corporation, St. Joseph, MI, U.S.). Starch content was determined by Ewers' polarimetric method, the fibre content gravimetrically after oxidative hydrolysis by strong acids, $\beta$-glucans enzymatically using the $\beta$-glucan enzymatic assay kit (Megazyme Ireland International, Ltd., Wicklow, Ireland). Crude fat content was measured using Soxhlet extraction with petroleum ether (Javorský et al., 1987).

Table 2: Yield and quality of 2 varieties of hulless barley grown under inoculation (I) by Fusarium culmorum, in comparison with non-inoculated (NI) control, Kroměřiž 2015-2017

\begin{tabular}{|c|c|c|c|c|c|c|c|c|c|c|c|c|}
\hline \multirow{2}{*}{$\begin{array}{c}\text { Harvest } \\
\text { year }\end{array}$} & \multirow[t]{2}{*}{ Variant } & \multirow[t]{2}{*}{ Variety } & DON & $\begin{array}{l}\text { Grain } \\
\text { yield }\end{array}$ & TKW & TW & CPC & BG & Starch & Fat & Fiber & GER \\
\hline & & & $\mu \mathrm{g} / \mathrm{kg}$ & t/ha & $\mathrm{g}$ & $\mathrm{kg} / \mathrm{hl}$ & $\%$ & $\%$ & $\%$ & $\%$ & $\%$ & $\%$ \\
\hline 2015 & $\mathrm{NI}$ & AF Cesar & $23 \pm 9$ & $7.1 \pm 0.1$ & $51.1 \pm 0.5$ & $78.7 \pm 1.0$ & $13.3 \pm 0.3$ & $5.6 \pm 0.1$ & $62.8 \pm 1.3$ & $3.2 \pm 0.2$ & $1.4 \pm 0.3$ & $98.2 \pm 1.1$ \\
\hline 2015 & $\mathrm{NI}$ & AF Lucius & $38 \pm 13$ & $7.6 \pm 0.4$ & $45.0 \pm 2.8$ & $73.7 \pm 1.3$ & $13.0 \pm 0.3$ & $4.5 \pm 0.1$ & $64.4 \pm 0.7$ & $2.8 \pm 0.2$ & $1.8 \pm 0.2$ & $98.5 \pm 0.8$ \\
\hline 2016 & $\mathrm{NI}$ & AF Cesar & $<20$ & $6.4 \pm 0.5$ & $49.8 \pm 0.5$ & $81.7 \pm 0.1$ & $15.9 \pm 0.3$ & $5.9 \pm 0.6$ & $61.3 \pm 0.5$ & $3.5 \pm 1.2$ & $1.3 \pm 0.5$ & $96.3 \pm 2.4$ \\
\hline 2016 & $\mathrm{NI}$ & AF Lucius & $20 \pm 8$ & $7.0 \pm 0.1$ & $46.9 \pm 0.5$ & $81.6 \pm 0.8$ & $13.8 \pm 0.1$ & $4.6 \pm 0.5$ & $64.0 \pm 0.7$ & $2.6 \pm 0.8$ & $1.1 \pm 0.2$ & $96.8 \pm 1.4$ \\
\hline 2017 & $\mathrm{NI}$ & AF Cesar & $<20$ & $6.5 \pm 0.4$ & $46.1 \pm 0.4$ & $76.8 \pm 0.5$ & $13.9 \pm 0.5$ & $5.0 \pm 0.1$ & $63.9 \pm 1.5$ & $3.3 \pm 0.3$ & $1.8 \pm 0.2$ & $95.8 \pm 3.6$ \\
\hline 2017 & $\mathrm{NI}$ & AF Lucius & $<20$ & $7.0 \pm 0.2$ & $41.3 \pm 0.9$ & $72.1 \pm 0.4$ & $13.0 \pm 0.2$ & $4.2 \pm 0.1$ & $65.1 \pm 0.9$ & $2.8 \pm 0.3$ & $1.9 \pm 0.2$ & $97.6 \pm 2.5$ \\
\hline mean NI & & & $<20$ & $6.9 \pm 0.5$ & $46.7 \pm 3.5$ & $77.4 \pm 3.8$ & $13.8 \pm 1.1$ & $5.0 \pm 0.7$ & $63.6 \pm 1.6$ & $3.1 \pm 0.6$ & $1.5 \pm 0.4$ & $97.2 \pm 2.2$ \\
\hline 2015 & 1 & AF Cesar & $3053 \pm 387$ & $6.9 \pm 0.1$ & $49.5 \pm 0.4$ & $77.1 \pm 0.9$ & $13.6 \pm 0.2$ & $5.4 \pm 0.1$ & $62.8 \pm 0.5$ & $3.1 \pm 0.2$ & $1.6 \pm 0.2$ & $93.3 \pm 2.1$ \\
\hline 2015 & I & AF Lucius & $1503 \pm 224$ & $7.5 \pm 0.4$ & $47.4 \pm 1.0$ & $75.4 \pm 0.8$ & $12.8 \pm 0.6$ & $4.6 \pm 0.0$ & $64.4 \pm 0.7$ & $2.7 \pm 0.1$ & $1.7 \pm 0.2$ & $96.4 \pm 1.5$ \\
\hline 2016 & I & AF Cesar & $2649 \pm 347$ & $6.3 \pm 0.4$ & $48.2 \pm 0.8$ & $80.9 \pm 0.3$ & $15.8 \pm 0.3$ & $5.7 \pm 0.1$ & $61.5 \pm 0.5$ & $3.0 \pm 1.2$ & $1.1 \pm 0.2$ & $89.0 \pm 2.3$ \\
\hline 2016 & I & AF Lucius & $809 \pm 139$ & $6.9 \pm 0.3$ & $46.9 \pm 0.8$ & $81.2 \pm 0.2$ & $13.6 \pm 0.2$ & $4.6 \pm 0.2$ & $64.8 \pm 0.9$ & $2.6 \pm 1.2$ & $1.2 \pm 0.1$ & $97.4 \pm 1.3$ \\
\hline 2017 & 1 & AF Cesar & $<20$ & $6.7 \pm 0.2$ & $45.1 \pm 1.4$ & $77.1 \pm 0.7$ & $13.7 \pm 0.1$ & $5.1 \pm 0.1$ & $63.2 \pm 0.8$ & $3.2 \pm 0.3$ & $1.6 \pm 0.2$ & $96.0 \pm 3.6$ \\
\hline 2017 & 1 & AF Lucius & $<20$ & $6.5 \pm 0.1$ & $41.7 \pm 0.5$ & $73.5 \pm 1.0$ & $12.5 \pm 0.3$ & $4.2 \pm 0.0$ & $65.0 \pm 0.5$ & $2.7 \pm 0.3$ & $1.8 \pm 0.2$ & $96.1 \pm 3.3$ \\
\hline mean I & & & $1340 \pm 1302$ & $6.8 \pm 0.5$ & $46.5 \pm 2.7$ & $77.5 \pm 2.9$ & $13.7 \pm 1.1$ & $4.9 \pm 0.5$ & $63.6 \pm 1.4$ & $2.9 \pm 0.7$ & $1.5 \pm 0.3$ & $94.7 \pm 3.6$ \\
\hline
\end{tabular}

TKW - thousand kernel weight, TW - test weight, CPC - crude protein content, BG - $\beta$-glucan content, GER germination 


\subsection{DON analysis}

The DON content was analyzed in whole meal flour by an ELISA method using R-Biopharm AG kits (Darmstadt, Germany), according to the manufacturer's instructions. A combination of RIDASCREEN ${ }^{\circledR}$ DON and RIDACREEN ${ }^{\circledR}$ FAST DON kits was used, with the limit of quantification (LOQ) equal to $20 \mu \mathrm{g} / \mathrm{kg}$. The method has been accredited in the laboratory according to Czech national standard ČSN EN ISO/IEC 17025. Samples with high contamination were diluted 10 times in distilled water. Whole meal flour was obtained by milling $200 \mathrm{~g}$ of sample with a sample mill (Pulverisette 19, Fritsch, Idar-Oberstein, Germany), using a $1 \mathrm{~mm}$ screen. Samples were stored at $-20^{\circ} \mathrm{C}$ until analyses.

\subsection{Data analyses}

The analytical data were reported as mean \pm standard deviation of four field replications. Normality of data was assessed using Shapiro-Wilk test. The data from three years and two locations were tested by a four-way ANOVA. Statistical comparison of the means was made by post-ANOVA Tukey (HSD) test when significant main effects were detected. To calculate mean DON values, the results reported as below $L O Q$ were replaced by half their respective $L O Q$ (middle bound estimate). For comparison of DON levels, the paired t-test was applied on log-transformed values. All calculations were performed using the STATISTICA Cz 12 software package (StatSoft, CR s.r.o). $p<0.05$ was considered significant.

\section{Results}

\subsection{DON content}

Under conditions of natural infection (NI), the DON content was very low at both sites (Tables 2, 3). Inoculation (I) significantly increased the DON content in KM for both varieties in 2015 and 2016. Inoculation in KM in 2017 was not successful, both varieties having the content of DON $<\mathrm{LOQ}$, just like the $\mathrm{NI}$ variants. In ZB, the mean of I variants in all years was slightly higher $(50 \mu \mathrm{g} / \mathrm{kg})$ than the mean of $\mathrm{NI}$ variants $(25 \mu \mathrm{g} / \mathrm{kg})$, but the increase was not conclusive. Inoculation was generally more successful in Kromeříž (average DON content (1 $340 \pm 1302) \mu \mathrm{g} / \mathrm{kg}$ ) than in Zubří (50 \pm 18$) \mu \mathrm{g} / \mathrm{kg})$. The difference between varieties in DON content was inconclusive in the I variants (mean: AF Cesar $(979 \pm 1456) \mu \mathrm{g} / \mathrm{kg}$, AF Lucius (412 \pm 617) $\mu \mathrm{g} / \mathrm{kg}$ ), However, mean DON values were low and were around LOQ: AF Cesar < LOQ, AF Lucius $(27 \pm 20)$ $\mu \mathrm{g} / \mathrm{kg}$.

\subsection{Barley yield, TKW and TW}

Reduction of grain yield after $F$. culmorum inoculation was significant (Table 4) but, as post-ANOVA Tukey (HSD) test revealed, only at ZB in harvest year 2017 (NI: $6.06 \mathrm{t} /$ ha, I: $4.29 \mathrm{t} / \mathrm{ha}$ ). The strongest factor influencing yield was location (L) $(\mathrm{ZB}<\mathrm{KM})$, explaining almost $70 \%$ of yield variability. Significant influence was also exerted by harvest year (Y) $(2016<2015<2017)$, genotype (G) (AF Cesar $<\mathrm{AF}$ Lucius) and interaction $\mathrm{Y} \times \mathrm{L}$.

Table 3: Yield and quality of 2 varieties of hulless barley grown under inoculation (I) by Fusarium culmorum, in comparison with non-inoculated (NI) control, Zubří 2015-2017

\begin{tabular}{|c|c|c|c|c|c|c|c|c|c|c|c|c|}
\hline \multirow{2}{*}{$\begin{array}{c}\text { Harvest } \\
\text { year }\end{array}$} & \multirow{2}{*}{ Variant } & \multirow{2}{*}{ Variety } & DON & Grain yield & TKW & TW & CPC & BG & starch & fat & fiber & GER \\
\hline & & & $\mu \mathrm{g} / \mathrm{kg}$ & t/ha & g & $\mathrm{kg} / \mathrm{hl}$ & $\%$ & $\%$ & $\%$ & $\%$ & $\%$ & $\%$ \\
\hline 2015 & $\mathrm{NI}$ & AF Cesar & $<20$ & $2.7 \pm 0.2$ & $43.9 \pm 0.2$ & $74.9 \pm 0.7$ & $14.9 \pm 0.3$ & $5.5 \pm 0.2$ & $60.6 \pm 0.6$ & $2.9 \pm 0.3$ & $1.8 \pm 0.2$ & $90.9 \pm 1.4$ \\
\hline 2015 & $\mathrm{NI}$ & AF Lucius & $21 \pm 8$ & $2.8 \pm 0.2$ & $41.2 \pm 0.6$ & $72.8 \pm 1.2$ & $13.5 \pm 0.3$ & $4.4 \pm 0.1$ & $62.7 \pm 0.9$ & $2.7 \pm 0.4$ & $1.8 \pm 0.2$ & $93.3 \pm 1.6$ \\
\hline 2016 & $\mathrm{NI}$ & AF Cesar & $26 \pm 10$ & $1.7 \pm 0.3$ & $44.5 \pm 0.9$ & $67.1 \pm 0.7$ & $17.6 \pm 0.2$ & $4.9 \pm 0.2$ & $58.9 \pm 1.2$ & $3.2 \pm 0.9$ & $1.9 \pm 0.2$ & $93.6 \pm 3.0$ \\
\hline 2016 & $\mathrm{NI}$ & AF Lucius & $61 \pm 19$ & $2.5 \pm 0.2$ & $44.9 \pm 0.6$ & $66.3 \pm 0.6$ & $15.4 \pm 0.4$ & $4.5 \pm 0.3$ & $62.0 \pm 0.7$ & $2.9 \pm 0.5$ & $1.9 \pm 0.2$ & $95.5 \pm 3.0$ \\
\hline 2017 & $\mathrm{NI}$ & AF Cesar & $<20$ & $5.6 \pm 0.7$ & $47.7 \pm 1.0$ & $68.4 \pm 1.0$ & $14.1 \pm 0.3$ & $5.6 \pm 0.1$ & $60.7 \pm 0.9$ & $3.0 \pm 0.1$ & $2.3 \pm 0.4$ & $95.0 \pm 1.7$ \\
\hline 2017 & $\mathrm{NI}$ & AF Lucius & $<20$ & $6.6 \pm 1.0$ & $44.9 \pm 1.1$ & $66.1 \pm 1.7$ & $11.5 \pm 0.2$ & $4.1 \pm 0.0$ & $64.6 \pm 0.9$ & $2.4 \pm 0.3$ & $2.5 \pm 0.2$ & $95.8 \pm 1.7$ \\
\hline mean NI & & & $25 \pm 18$ & $3.6 \pm 1.9$ & $44.5 \pm 2.1$ & $69.3 \pm 3.6$ & $14.5 \pm 1.9$ & $4.8 \pm 0.6$ & $61.6 \pm 2.0$ & $2.0 \pm 0.3$ & $2.9 \pm 0.5$ & $94.0 \pm 2.6$ \\
\hline 2015 & 1 & AF Cesar & $61 \pm 19$ & $2.5 \pm 0.3$ & $42.4 \pm 0.4$ & $73.2 \pm 1.1$ & $14.9 \pm 0.2$ & $5.3 \pm 0.2$ & $61.3 \pm 1.0$ & $2.8 \pm 0.1$ & $1.6 \pm 0.1$ & $92.2 \pm 2.2$ \\
\hline 2015 & I & AF Lucius & $66 \pm 20$ & $2.2 \pm 0.1$ & $39.8 \pm 0.8$ & $72.8 \pm 1.3$ & $13.4 \pm 0.2$ & $4.4 \pm 0.2$ & $63.4 \pm 0.4$ & $2.5 \pm 0.1$ & $1.5 \pm 0.2$ & $93.3 \pm 1.3$ \\
\hline 2016 & 1 & AF Cesar & $62 \pm 19$ & $1.8 \pm 0.1$ & $44.1 \pm 1.0$ & $68.6 \pm 0.8$ & $16.9 \pm 0.2$ & $5.0 \pm 0.2$ & $60.7 \pm 0.2$ & $3.5 \pm 0.7$ & $1.4 \pm 0.3$ & $91.5 \pm 1.5$ \\
\hline 2016 & 1 & AF Lucius & $25 \pm 9$ & $2.6 \pm 0.6$ & $44.8 \pm 0.7$ & $67.8 \pm 0.5$ & $14.3 \pm 0.1$ & $4.4 \pm 0.2$ & $63.4 \pm 0.9$ & $3.1 \pm 0.7$ & $1.8 \pm 0.3$ & $93.1 \pm 1.3$ \\
\hline 2017 & 1 & AF Cesar & $31 \pm 11$ & $4.2 \pm 1.2$ & $46.1 \pm 0.9$ & $67.9 \pm 1.0$ & $13.2 \pm 0.1$ & $5.3 \pm 0.2$ & $61.9 \pm 1.4$ & $2.8 \pm 0.2$ & $2.1 \pm 0.2$ & $95.9 \pm 0.8$ \\
\hline 2017 & I & AF Lucius & $55 \pm 17$ & $4.4 \pm 1.3$ & $42.5 \pm 0.5$ & $64.5 \pm 1.2$ & $10.6 \pm 0.1$ & $3.9 \pm 0.1$ & $65.7 \pm 0.7$ & $2.2 \pm 0.3$ & $2.6 \pm 0.2$ & $97.1 \pm 1.9$ \\
\hline mean I & & & $50 \pm 18$ & $2.9 \pm 1.2$ & $43.3 \pm 2.2$ & $69.1 \pm 3.2$ & $13.9 \pm 2.0$ & $4.7 \pm 0.5$ & $62.8 \pm 1.9$ & $1.8 \pm 0.4$ & $2.8 \pm 0.6$ & $93.8 \pm 2.5$ \\
\hline
\end{tabular}

TKW - thousand kernel weight, TW - test weight, CPC - crude protein content, BG - $\beta$-glucan content, GER germination 
Table 4: The response of inoculation of 2 hulless barley varieties (AF Lucius, AF Cesar) by $\mathrm{F}$. culmorum on grain yield and quality parameters.

\begin{tabular}{|c|c|c|c|c|c|c|c|c|c|c|}
\hline Effect & Df & Yield & TKW & TW & CPC & BG & Starch & Fat & Fibre & GER \\
\hline Year (Y) & 2 & 0.0000 & 0.0000 & 0.0000 & 0.0000 & 0.0000 & 0.0000 & 0.26 & 0.0000 & 0.0006 \\
\hline Locality (L) & 1 & 0.0000 & 0.0000 & 0.0000 & 0.0000 & 0.0001 & 0.0000 & 0.29 & 0.0000 & 0.0000 \\
\hline Genotype (G) & 1 & 0.0001 & 0.0000 & 0.0000 & 0.0000 & 0.0000 & 0.0000 & 0.0002 & 0.0128 & 0.0000 \\
\hline Inoculation (I) & 1 & 0.0001 & 0.0003 & 0.96 & 0.0000 & 0.14 & 0.0013 & 0.37 & 0.0188 & 0.0031 \\
\hline$Y \times L$ & 2 & 0.0000 & 0.0000 & 0.0000 & 0.0000 & 0.0000 & 0.36 & 0.08 & 0.0000 & 0.0023 \\
\hline$Y \times G$ & 2 & 0.22 & 0.0000 & 0.0000 & 0.0000 & 0.08 & 0.0356 & 0.72 & 0.13 & 0.14 \\
\hline$L \times G$ & 1 & 0.96 & 0.0001 & 0.0256 & 0.0000 & 0.36 & 0.0123 & 0.70 & 0.63 & 0.30 \\
\hline$Y \times T$ & 2 & 0.0016 & 0.35 & 0.19 & 0.0000 & 0.89 & 0.19 & 0.90 & 0.45 & 0.0209 \\
\hline $\mathrm{L} \times \mathrm{T}$ & 1 & 0.0077 & 0.0135 & 0.60 & 0.0001 & 0.39 & 0.0018 & 0.57 & 0.05 & 0.0092 \\
\hline $\mathrm{G} \times \mathrm{T}$ & 1 & 0.13 & 0.0049 & 0.0161 & 0.07 & 0.33 & 0.78 & 0.82 & 0.21 & 0.13 \\
\hline$Y \times L \times G$ & 2 & 0.10 & 0.19 & 0.0064 & 0.0001 & 0.0000 & 0.0156 & 0.78 & 0.08 & 0.35 \\
\hline$Y \times L \times T$ & 2 & 0.0016 & 0.0215 & 0.0002 & 0.06 & 0.08 & 0.62 & 0.52 & 0.21 & 0.32 \\
\hline $\mathrm{Y} \times \mathrm{G} \times \mathrm{T}$ & 2 & 0.37 & 0.20 & 0.0127 & 0.82 & 0.38 & 0.96 & 0.80 & 0.16 & 0.11 \\
\hline $\mathrm{L} \times \mathrm{G} \times \mathrm{T}$ & 1 & 0.55 & 0.0030 & 0.07 & 0.36 & 0.66 & 0.50 & 0.54 & 0.21 & 0.06 \\
\hline$Y \times L \times G \times T$ & 2 & 0.94 & 0.36 & 0.59 & 0.43 & 0.31 & 0.87 & 0.88 & 0.87 & 0.05 \\
\hline
\end{tabular}

Df - degree of freedom, TKW - thousand kernel weight, TW - test weight, CPC - crude protein content, BG $\beta$-glucan content, GER - germination

Also the reduction of TKW as a consequence of inoculation was statistically significant (NI: $45.61 \mathrm{~g}$, I: $44.88 \mathrm{~g}$ ) within the frames of the whole data set, with significant interactions with genotype and location, and also higher interactions were observed. Significant TKW reduction was proved in ZB for variety AF Lucius (NI: $43.65 \mathrm{~g}$, I: $42.39 \mathrm{~g}$ ) and in KM for AF Cesar (NI: $49.00 \mathrm{~g}$, I: $47.61 \mathrm{~g}$ ). TKW was influenced mainly by the environment - the most important was the combined interaction $\mathrm{YxL}$, and significant were also location ( $\mathrm{ZB}<\mathrm{KM})$, variety ( $\mathrm{AF}$ Lucius $<\mathrm{AF}$ Cesar) and harvest year $(2017<2015<2016)$.

TW was significantly reduced by the inoculation only in harvest year 2015 for variety AF Cesar (NI: $76.82 \mathrm{~kg} / \mathrm{hl}$, I: $75.17 \mathrm{~kg} / \mathrm{hl})$. The main factor influencing TW was location $(\mathrm{ZB}<\mathrm{KM})$, followed by the interaction $\mathrm{YxL}$, harvest year $(2017<2016=2015)$ and variety itself $(A F$ Lucius $<$ AF Cesar), and $\mathrm{YxG}$.

\subsection{Germination}

Germination of barley was significantly reduced by inoculation (NI: $95.6 \%$, I: $94.3 \%$ ) (Table 4), but the difference was significant at KM only (I: $94.7 \%$, NI: $97.2 \%$ ). More important factors than inoculation were proved to be location (ZB $<\mathrm{KM})$, variety (AF Cesar $<\mathrm{AF}$ Lucius) and harvest year $(2016-2015<2017)$.

\subsection{Content of protein, starch, fat and fiber}

CPC was significantly lower after $F$. culmorum inoculation over all harvest years, both locations and varieties (NI: $14.2 \%$; I: $13.8 \%$ ) (Table 4). There were significant interactions with harvest year - the influence was significant in 2017 (NI: 13.1\%, I: 12.5\%) and 2016 (NI: 15.7\%, I: 15.2\%) but not in 2015, and location - the influence was significant at ZB only (NI: $15.5 \%$, I: $13.9 \%$ ). A more important factor influencing CPC than inoculation was harvest year (2017 $<2015<2016$ ), variety (AF Lucius $<$ AF Cesar), location $(\mathrm{KM}<\mathrm{ZB})$ and their interactions. Content of starch was significantly higher after inoculation (NI: $62.6 \%$; I: $63.2 \%$ ), fiber was lower (NI: $1.8 \%$; I: $1.7 \%$ ). Starch content was influenced by the inoculation only at ZB (NI: $61.6 \%$; I: $62.8 \%)$. The main factor influencing starch content was variety (AF Cesar $<$ AF Lucius), followed by location (ZB $<\mathrm{KM})$ and harvest year $(2016<2015<2017)$. Harvest year was also the main influencing factor for fiber $(2016<$ $2015<2017)$, followed by location $(K M<Z B)$ and variety (AF Cesar $<$ AF Lucius). The content of both $\beta$-glucan and fat was not influenced by the inoculation. The only factor influencing fat content was variety (AF Lucius $<A F$ Cesar).

\subsection{Content of $\beta$-glucans}

Variety was the main factor influencing $\beta$-glucan content - AF Lucius: $4.36 \%$, AF Cesar: $5.35 \%$, but also harvest year $-2017: 4.66 \%, 2016=2015: 4.95 \%$ and location $-Z B$ : $4.76 \%, \mathrm{KM}: 4.94 \%$ were significant, with significant mutual interactions YxL and YxLxG (Fig. 1). 


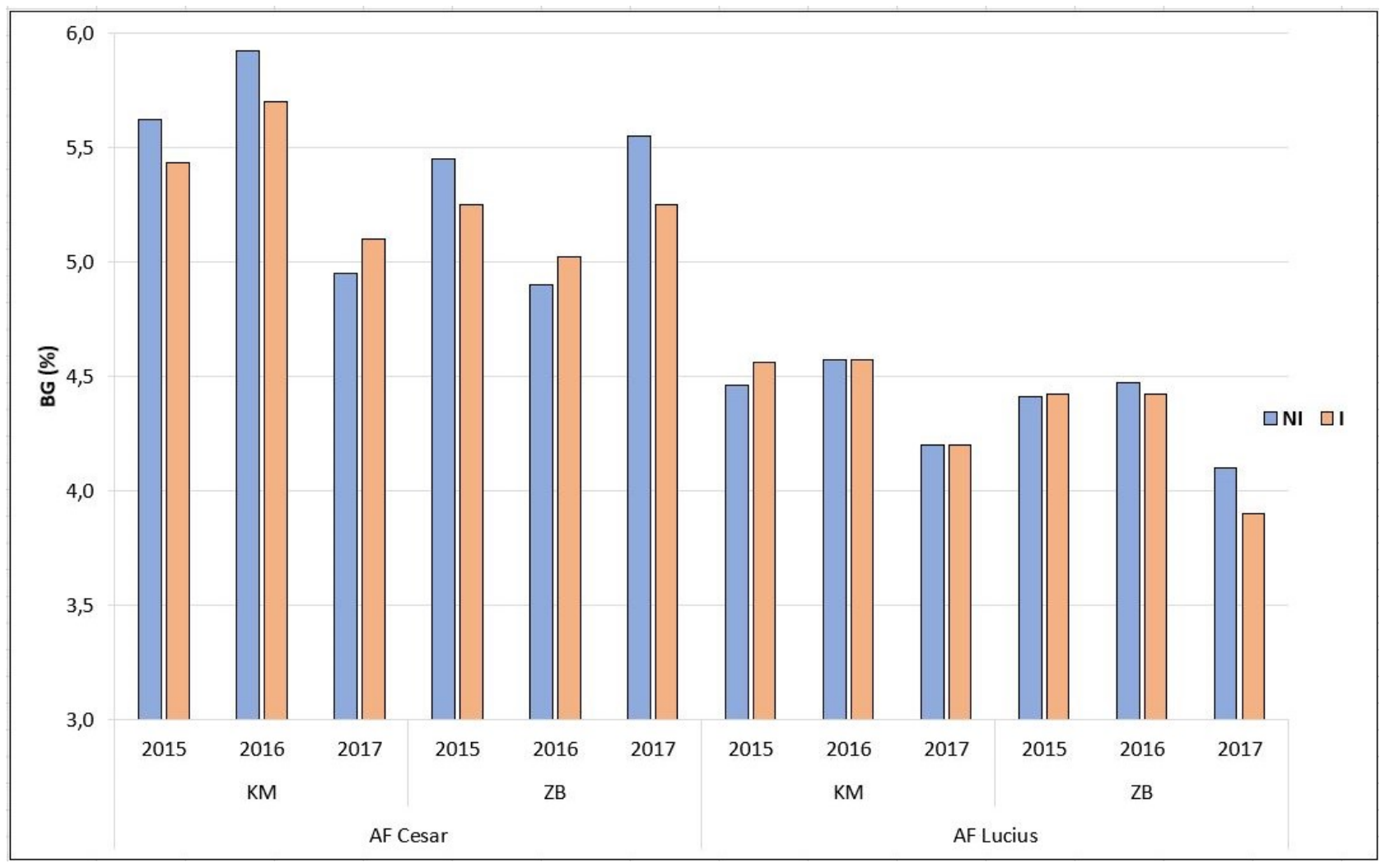

Figure 1: $\beta$-Glucan content in the grains of 2 varieties of naked barley (AF Cesar, AF Lucius) grown at 2 localities (KM - Kroměřǐz, ZB - Zubří). I - inoculation by F. culmorum, NI- natural infection.

\section{Discussion}

$F$. culmorum and $F$. graminearum are potent producers of type B trichothecenes (DON, nivalenol) and zearalenone. These two species are considered the most harmful of the FHB complex (Nielsen et al., 2014). The aim of our work was to determine the effect of inoculation of two varieties of hulless barley with the $F$. culmorum pathogen on yield, quality including $\beta$-glucan content and level of DON contamination. Because environmental conditions play a significant role in FHB epidemiology, our experiments were based on two climatically different experimental sites in Kromeříz (warmer and drier locality) and Zubří (cooler and wetter habitat). The monitoring was carried out in 3 consecutive harvest years 2015-2017. In the conditions of natural infection, the DON content did not exceed 70 $\mu \mathrm{g} / \mathrm{kg}$ in any one of the harvest years and was therefore very low compared with the DON content in food cereals $(1250 \mu \mathrm{g} / \mathrm{kg})$, AF Cesar had an average DON content under natural infection conditions lower than AF Lucius, while under inoculation conditions the content in both varieties was comparable. The difference may be due to the considerable variability of DON level under inoculation conditions.

Throughout the experiment, the yield was reduced by an average of $8 \%$ after inoculation by $F$. culmorum, with a proven variation in the variety and the environment. Tekauz et al. (2000) report that loss of yield due to the infection by Fusarium pathogens is relatively small in barley because the infected barley grains are only slightly lighter and smaller than healthy kernels. TKW after inoculation was significantly lower in Zubří for AF Lucius, in Kroměříž for AF Cesar, the drop being approximately $3 \%$ in both varieties. In the case of AF Cesar, a significant drop in TKW has also been recorded across the data set. Significant dependence of TKW reduction in barley (in the range of $2-20 \%$ ) on genotype and environment was also reported by Martin et al. (2018). No comparative literature data are as yet available for hulless barley. TW was significantly reduced by inoculation only for AF Cesar in 2015 (2.2\%), in this year it also had the highest DON content $(3053 \mu \mathrm{g} / \mathrm{kg})$.

The CPC content was significantly lower for the inoculated variants, on average less than $3 \%$ (relative), but the reaction was subject to interaction with the environment and a demonstrable reduction in CPC appeared only in Zubrí, in 2017 for both varieties and in 2016 for the AF Lucius variety. Although DON content was relatively low in these inoculated variants, the reduction in protein content was $7.3 \%-8.2 \%$ (relative). Inoculation was probably not the only cause of this CPC decline in Zubří, especially in 2017, when it was also associated with a significant decline in yield. Conversely, changes in NL content were negligible for inoculated varieties in Kroměříz with a high content of DON (2015 and 2016). Eggert and Pawelzik (2011) reported that even a strong Fusarium infection did not lead to the destruction of grain storage proteins in hulless barley. They assumed that some defense mechanisms of the plant must exist to protect naked barley grains from the destruction of their nutrient reservoir proteins and reduce infection degree. 
In the data from the entire inoculation assay the germination was significantly reduced. Although the influence of locality, harvest year and their interaction and germination variations was greater than the effect of inoculation, germination was the parameter most affected by inoculation. In Kroměř́ž in 2016, the germination rate for AF Cesar fell by $7.3 \%$ (DON $2649 \mu \mathrm{g} / \mathrm{kg}$ ), in 2015 in both varieties (AF Cesar by $4.9 \%$ - DON $3053 \mu \mathrm{g} / \mathrm{kg}$, AF Lucius by $2.1 \%$ $1503 \mu \mathrm{g} / \mathrm{kg})$.

The $\beta$-glucan content was strongly influenced by the variety, which explained more than $70 \%$ of all variations in the glucan content. It was significantly higher in AF Cesar (5.35\%) compared to AF Lucius (4.36\%) (Figure 1). Inoculation did not affect $\beta$-glucan content. Martin et al. (2018) found a significant and inverse relationship between DON contamination and $\beta$-glucan content for covered barley after inoculation with $F$. graminearum. They suggested that high $\beta$-glucan content, probably because of its antioxidant activity, contributes to the resistance against toxin accumulation. Our results are unambiguous in this respect. Under conditions of natural infection, Cesar AF with a significantly higher $\beta$-glucan content had a DON content lower than AF Lucius, but after inoculation, the DON content of the two varieties was comparable.

\section{References}

Eggert, K., Wieser, H., Pawelzik, E. 2010a. The influence of Fusarium infection and growing location on the quantitative protein composition of (Part I) emmer (Triticum dicoccum). Eur. J. Food Res. Technol. 230, 837-848.

Eggert, K., Wieser, H., Pawelzik, E. 2010b. The influence of Fusarium infection and growing location on the quantitative protein composition of (part II) naked barley (Hordeum vulgare nudum), Eur. Food Res. Technol. 230, 893-902, http://dx.doi.org/10.1007/s00217-010-1234-6

Eggert, K., Pawelzik, E., 2011. Proteome analysis of Fusarium head blight in grains of naked barley (Hordeum vulgare subsp. nudum). Proteomycs, 11(5): 972-985. DOI: 10.1002/pmic.201000322

EU, 2006. Commission Regulation (EC) No. 1881/2006 of 19 December 2006 setting maximum levels for certain contaminants in foodstuffs. OJ L 364, 20.12.2006, p. 5

Fernandez, M.R., Zentner, R.P., DePauw, R.M., Gehl, D. and Stevenson, F.C., 2007. Impacts of crop production factors on Fusarium Head Blight in barley in Eastern Saskatchewan. Crop Science 47: 1574-1584.

Idehen, E., Tang, Y., Sang., S., 2017. Bioactive phytochemicals in barely. J. Food Drug Anal., 25(1): 148-161. DOI: 10.1016/j.jfda.2016.08.002

Javorský, P., Fojtíková, D., Kalaš, V., Schwarz, M. Chemické rozbory $v$ zemědělských laboratořích, I. díl (vydalo ministerstvo zemědělství a výživy ČSR, ve Výstavnictví zemědělství a výživy České Budějovice, 1987), $397 \mathrm{p}$.

Kreuzberger, M., Limsuwan, S., Eggert, K., Karlovsky, P., Pawelzik, E., 2015. Impact of Fusarium spp. infection of bread wheat (Triticum aestivum L.) on composition and quality of flour in

\section{Conclusion}

The good news for consumers of hulless barley products, including whole-grain ones, is its very low level of contamination with DON mycotoxin. Inoculation with the $F$. culmorum pathogen affected most strongly germination, to some extent yield and quality while the variety, environment and their interactions had a major influence on the parameters monitored. The relationship between $\beta$-glucans as effective antioxidants and the resistance of the variety to DON accumulation was unambiguously confirmed. To clarify a possible relationship, it would be advisable to study this under inoculation conditions with other Fusarium species and include more genotypes with different $\beta$-glucan content.

\section{Acknowledgements}

The research was funded by the Ministry of Agriculture, project No. QJ1510204.

association with EU maximum level for deoxynivalenol. J. Appl. Bot. Food Qual., 88: 177-185.

Martin, C., Schöneberg, T., Vogelgsang, S., Morisoli, R., Bertossa, M., Mauch-Mani, B., Mascher, F., 2018. Resistance against Fusarium graminearum and the relationship to $\beta$-glucan content in barley grains. Eur. J. Plant Pathol., 152: 621. DOI: 10.1007/s10658-018-1506-8

Nielsen, L. K., Cook, D. J., Edwards, S. G., Ray, R. V., 2014. The prevalence and impact of Fusarium head blight pathogens and mycotoxins on malting barley quality in UK. Int. J. Food Microbiol., 179: 38-49. DOI: 10.1016/j.ijfoodmicro.2014.03.023 Sarlin, T., Laitila, A., Pekkarinen, A., Haikara, A., 2005. Effects of three Fusarium species on the quality of barley and malt. Am. Soc. Brew. Chem. 63, 43-49.

Schwarz, P. B., 2003. Impact of Fusarium head blight on malting and brewing quality of barley. In: Leonard, K. J., Bushnell, W. R. (eds.). Fusarium head blight of wheat and barley. APS Press; St. Paul, Minnesota, USA: 395-419. ISBN: 978-0-89054-302-3. Schwarz, P. B., Horsley, R. D., Steffenson, B. J., Salas B., Barr, J. M., 2006. Quality risks associated with the utilization of Fusarium head blight infected malting barley. J. Am. Soc. Brew. Chem., 64: 1-7.

Tekauz, A., McCallum, B., Gilbert, J., 2000. Review: Fusarium head blight of barley in western Canada. Can. J. Plant Pathol., 22(1): 9-16. DOI: 10.1080/07060660009501156

Tibola, C. S., Fernandes, J. M. C., Guarienti, E. M., Nicolau, M., Distribution of Fusarium mycotoxins in wheat milling proces., Food Control, 53: 91-95. DOI: 10.1016/j.foodcont.2015.01.012 Tvarůžek, L., Matušinsky, P., Vyšohlídová, M., 2012. Metodika pro zakládání a hodnocení pokusů s umělou inokulací obilnin fuzáriózami klasů. Agrotest fyto, Kroměříž. ISBN: 978-80-8755509-5. 